\title{
Haemophagocytic syndrome complicating acute lymphoblastic leukaemia
}

\author{
R. Stark and A. Manoharan
}

Department of Clinical Haematology, St George Hospital, University of New South Wales, Sydney, Australia

\begin{abstract}
Summary: A 41 year old female developed reactive haemophagocytic histiocytosis secondary to herpes simplex infection, during remission induction for acute lymphoblastic leukaemia. She recovered fully with acyclovir and supportive treatment. Previous publications on the association between acute lymphoblastic leukaemia and haemophagocytic syndrome are reviewed, and the nature of the haemophagocytic disorder is discussed.
\end{abstract}

\section{Introduction}

The haemophagocytic syndrome of histiocytic medullary reticulosis (HMR) is characterized by fever, weight loss, jaundice, lymphadenopathy, hepatosplenomegaly and pancytopenia, and by widespread organ infiltration by atypical histiocytes with variable haemophagocytosis. ${ }^{1}$ More than 200 cases have now been reported, some of them under the title 'malignant histiocytosis' (MH) - a term initially considered as a synonym for HMR. ${ }^{2,3}$ In recent years two further types of clinical disorders with features similar to those in HMR have been recognized: (i) a potentially selflimiting disease secondary to viral and other infections; ${ }^{4,5}$ (ii) a terminal complication in patients with a pre-existing haematological malignancy ${ }^{6-11}$ or carcinoma. ${ }^{12}$ This report describes a 41 year old female who developed a HMR-like syndrome during remission induction for acute lymphoblastic leukaemia (ALL).

\section{Case report}

A previously well 41 year old female presented in August, 1987 with a 2-week history of fever, night sweats, rhinorrhoea, malaise and fatigue. Examination revealed $1 \mathrm{~cm}$ lymph nodes palpable in both axillae and a tippable spleen. A blood count showed haemoglobin $9.2 \mathrm{~g} / \mathrm{dl}$, white cell count (WCC) $16.6 \times 10^{9} / 1$, with $59 \%$ blasts, $32 \%$ lymphocytes, $2 \%$ neutrophils, $6 \%$ monocytes, $1 \%$ eosinophils and platelets $53 \times 10^{9} / 1$. Bone marrow aspiration was hypercellular with a dense infiltration of blasts including a population of small cells with a high nuclear:cytoplasmic ratio and another of larger cells

Correspondence: A. Manoharan, M.D., F.R.A.C.P., F.R.C.P.A., St George Hospital, Kogarah, N.S.W. 2217, Australia.

Accepted: 1 November 1988 with more cytoplasm. Cytochemistry and surface markers were as shown in Table I, the leukaemia was thus classified as CALLA + ve ALL (FAB L2). Cytogenetic studies were 46XX (normal).

Remission induction chemotherapy was commenced with oral prednisolone $100 \mathrm{mg} / \mathrm{day}$ and vincristine $2 \mathrm{mg}$ intravenously/week. On day 2 the patient developed a herpes simplex lesion on the upper lip; acyclovir was commenced, with resolution over the ensuing 2 weeks. The splenomegaly and lymphadenopathy resolved and there was a prompt fall in the WCC with disappearance of all blast cells. However, despite the non-myelotoxic nature of the chemotherapy, the patient remained profoundly neutropenic and became more severely thrombocytopenic and anaemic: on day 18 the WCC was $0.8 \times 10^{9} / 1$ with $80 \%$ lymphocytes, $16 \%$ neutrophils and $2 \%$ monocytes; platelets $16 \times 10^{9} / 1$ and haemoglobin $8.4 \mathrm{~g} / \mathrm{dl}$. A repeat bone marrow aspiration showed markedly decreased myeloid precursors, $62 \%$ mature lymphocytes, $1 \%$ blasts and $22 \%$ abnormal mononuclear cells and macrophages, some showing erythrophagocytosis (Figure 1); a differential count of the mononuclearmacrophage cells showed predominance of mature macrophages over immature mononuclear cells by a ratio of $2.6: 1 ;{ }^{13}$ erythropoiesis was reduced $(10 \%)$ and markedly dyserythropoietic. Cytochemistry of the mononuclear cells (Table I) was consistent with monocytic origin. Biochemistry, including liver function tests and coagulation studies, was normal.

The ALL treatment protocol was continued and on days 20 and 21 daunorubicin $100 \mathrm{mg}$ i.v. was given. On day 30 the patient developed pneumonia; this resolved with intravenous antibiotics and leucocyte transfusions. On day 38 there was a recurrence of labial herpes simplex which settled with oral acyclovir. There was a further fall in the leucocyte and platelet counts

(C) The Fellowship of Postgraduate Medicine, 1989 


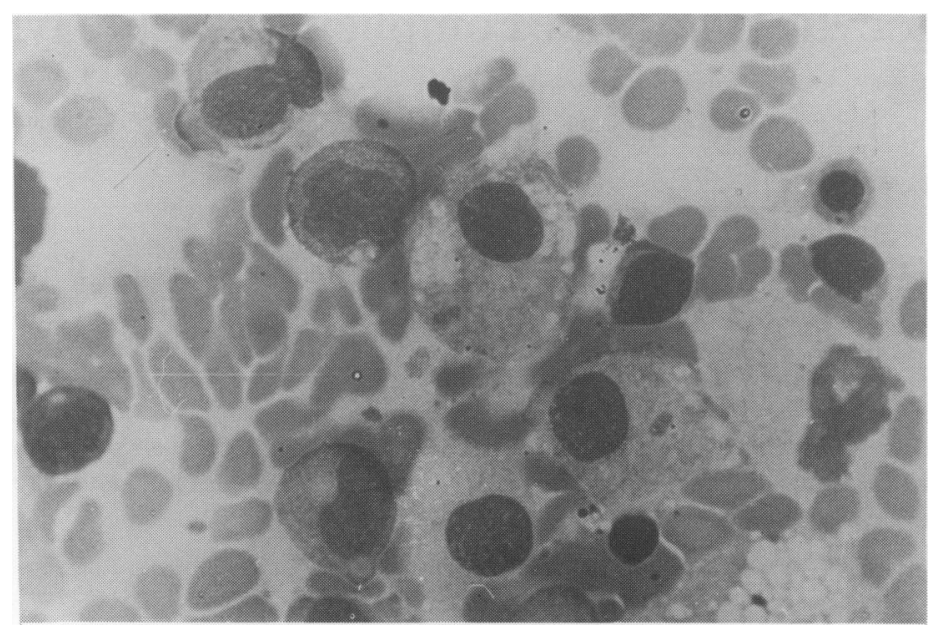

Figure 1 Bone marrow aspiration (May-Grünwald-Giemsa). Day 18 showing histiocytic proliferation $(\times 22)$.

Table I Bone marrow cytochemistry and surface markers

\begin{tabular}{lll}
\hline & 21.8 .87 & 8.9 .87 \\
\hline Sudan Black & Negative & Weak+ (diffuse) \\
PAS & $4+$ block & $4+$ diffuse \\
Dual esterase & N.D. & $2+$ \\
Acid esterase & Negative & N.D. \\
tdt & $4+$ & $3+$ \\
CD2 & $9 \%$ & N.D. \\
CD10 (CALLA) & $86 \%$ & N.D. \\
CD19 & $54 \%$ & N.D. \\
CD22 & $13 \%$ & N.D. \\
HLA DR & $21 \%$ & N.D. \\
IL2-R & $8 \%$ & N.D. \\
\hline
\end{tabular}

N.D. - not done.

after daunorubicin; however, by day 47 the haemoglobin was $15 \mathrm{~g} / \mathrm{dl}$, WCC was $5.1 \times 10^{9} / 1$ with $60 \%$ neutrophils, $32 \%$ lymphocytes, $2 \%$ monocytes, $2 \%$ band forms, $1 \%$ metamyelocytes, $3 \%$ myelocytes, and platelets $103 \times 10^{9} / 1$. A repeat bone marrow aspiration at this time showed complete remission with no evidence of the abnormal monocytoid cells seen on the previous examination. During the period of cytopenias the patient received two red cell transfusions and several prophylactic platelet transfusions. At presentation influenza $B$ (complement fixation) titres were raised to $>512$, these subsequently fell to 1:64. Herpes simplex antibody titres were raised to $1: 256$ at presentation and remained at this titre or at 1:128 on several occasions over the next 3 months.

Twelve months after presentation the patient is well on maintenance chemotherapy.

\section{Discussion}

A HMR-like syndrome has now been described in $19 \frac{7}{2}$ patients with ALL (Table II). The patient described here is the first in whom the abnormal histiocytic $\vec{\theta}$ infiltrate was demonstrated during remissiong induction for ALL. The majority of previous reported cases were diagnosed between 3 and 6 montk from presentation with ALL, and in all but one (Patient 17, Table II) this syndrome has been fatal, possibly due to more extensive organ involvement; in our case the histiocytic infiltrate was clinically confined to the bone marrow.

The HMR-like syndrome in ALL has been thought by some authors to represent a true malignancy (malignant histiocytosis, MH) ${ }^{19}$ but others have felt it to be a reactive process. ${ }^{24,25}$ There have been several theories to explain the development of MH in ALL: a common stem cell could give rise to $\mathrm{MH}$ when the ALL clone is suppressed by chemotherapy; ${ }^{17}$ an oncogenic agent could be taken up by histiocytes from dying leukaemic cells leading to malignant transformation; ${ }^{20}$ or, $\mathrm{MH}$ is induced by chemotherapy. ${ }^{23}$ On the other hand, Rosner and Grünwald, reviewing 17 D reported cases of this syndrome in ALL, have stressed that the majority of these patients probably had T-cell ALL, and postulated that the histiocytosis was a result of oversecretion of lymphokines by the neoplastic $N$ cells. ${ }^{27}$ This was also suggested by Jaffe $e t$ al. ${ }^{7}$ who $\mathbb{W}$ reported six cases of NHL, including two cases of $\underset{Z}{ }$ T-cell lymphoma, terminating in a HMR-like syn- 0 drome.

Distinction between reactive and malignant histiocytosis on cytological criteria has been difficult due 
to the heterogeneity of the abnormal cells. However, in an attempt to overcome this, abnormal mononuclearmacrophage cells (histiocytes) have been classified into five stages of maturation and a preponderance of more mature cells has been noted in reactive histiocytosis. ${ }^{13,28}$ In the patient described here, more mature macrophages (stages 4 and 5) outnumbered immature mononuclear cells (stages 1 and 3 ) by a ratio of 2.6:1, thus indicating a reactive histiocytosis. This and the short time (16 days) between the diagnosis of ALL and the demonstration of histiocytosis make a second malignancy unlikely, and she did not have a T-cell neoplasm. She did, however, have a herpes simplex infection with raised titres at presentation. Reactive histiocytosis has most commonly been secondary to the herpes group virus infections: cytomegalovirus, Epstein-Barr virus, $H$. simplex, $H$. zoster. ${ }^{4,29}$ An influenza-B infection immediately prior to the diagnosis of ALL was not associated with histiocytosis on the initial bone marrow examination, thus making it a less likely cause. It is also possible that the histiocytic reaction was exacerbated by the killing of malignant cells by chemotherapy. ${ }^{20}$

In summary, we present a patient who developed bone marrow histiocytosis soon after the onset of labial herpes simplex during remission induction for ALL. Acyclovir and supportive treatment resulted in complete resolution of the abnormal infiltrate despite continuation of chemotherapy. The occurrence of this HMR-like syndrome in patients with haematological malignancy should prompt the search for an underlying infection.

\section{Acknowledgements}

We wish to thank Dr Susan Gordon for critical review of the manuscript and Mrs Margaret Jenkins for secretarial assistance.

Table II Histiocytic medullary reticulosis-like syndrome complicating acute lymphoblastic leukaemia

\begin{tabular}{|c|c|c|c|c|c|}
\hline Patient no. & Sex/age (y) & Time to onset $H M R$ & Manifestations & Diagnosis & Ref.no. \\
\hline 1 & $\mathrm{M} / 17$ & $3 \mathrm{mths}$ & Fever, splenomegaly & Autopsy & 14 \\
\hline 2 & $\mathbf{M} / 17$ & $3 \mathrm{mths}$ & $\begin{array}{l}\text { Fever, hepatomegaly, } \\
\text { sudden death }\end{array}$ & Autopsy & 15 \\
\hline 3 & $\mathrm{~F} / 12$ & $6 \mathrm{mths}$ & Sepsis, bleeding & Autopsy & 16 \\
\hline 4 & $\mathrm{M} / 24$ & 3 mths & Fever, hepatosplenomegaly & $\begin{array}{l}\text { Scalene node } \\
\text { biopsy } \\
\text { Bone marrow } \\
\text { examination }\end{array}$ & 17 \\
\hline 5 & $\mathrm{M} / 4$ & $4 \mathrm{mths}$ & $\begin{array}{l}\text { Fever, hepatosplenomegaly, } \\
\text { lymphadenopathy, } \\
\text { pancytopenia }\end{array}$ & Bone marrow & 18 \\
\hline 6 & $\mathbf{M} / 13$ & $6 \mathrm{mths}$ & Splenomegaly, pancytopenia & Splenectomy & 19 \\
\hline 7 & $\mathbf{F} / 5$ & $4 \mathrm{mths}$ & $\begin{array}{l}\text { Fever, hepatosplenomegaly, } \\
\text { pancytopenia }\end{array}$ & $\begin{array}{l}\text { Bone marrow } \\
\text { Liver biopsy } \\
\text { Splenectomy }\end{array}$ & 19 \\
\hline 8 & $\mathrm{M} / 1 \frac{1}{2}$ & 4 mths & Fever, recurrent infections & Bone marrow & 20 \\
\hline $\left.\begin{array}{r}9 \\
10 \\
11 \\
12\end{array}\right\}$ & NS & NS & $\begin{array}{l}\text { ALL remission terminated by } \\
\text { pancytopenia, jaundice, } \\
\text { death }\end{array}$ & $\begin{array}{l}\text { Autopsy in three } \\
\text { cases; NS in } \\
\text { other }\end{array}$ & 21 \\
\hline 13 & $M / 14$ & $6 \mathrm{mths}$ & $\begin{array}{l}\text { Fever, hepatosplenomegaly, } \\
\text { pancytopenia }\end{array}$ & Autopsy & 22 \\
\hline 14 & $\mathrm{~F} / 54$ & 7 wks & Pancytopenia & Bone marrow & 23 \\
\hline 15 & $\mathbf{M} / 22$ & $3 \frac{1}{2}$ mths & $\begin{array}{l}\text { Fever, hepatosplenomegaly, } \\
\text { pancytopenia }\end{array}$ & Bone marrow & 24 \\
\hline 16 & $F / 42$ & 6 mths & NS & NS & 25 \\
\hline 17 & $\mathrm{M} / 6$ & 28 mths & $\begin{array}{l}\text { Fever, anaemia, leukopenia, } \\
\text { hepatomegaly }\end{array}$ & Bone marrow & 26 \\
\hline 18 & $\mathrm{M} / 12$ & 19 mths & $\begin{array}{l}\text { Hepatosplenomegaly, Blasts in } \\
\text { P.B., fever, jaundice }\end{array}$ & Autopsy & 8 \\
\hline 19 & $F / 41$ & 18 days & Pancytopenia & Bone marrow & This report \\
\hline
\end{tabular}

NS - not specified 


\section{References}

1. Scott, R.B. \& Robb-Smith, A.H.T. Histiocytic medullary reticulosis. Lancet 1939, ii: 194-198.

2. Rappaport, H. (ed.) Tumors of the hemopoietic system. In: Atlas of Tumor Pathology, Sect III, Fasc 8. Armed Forces Institute of Pathology, Washington, 1966, pp. 49, 442.

3. Lampert, I.A., Catovsky, D. \& Bergier, N. Malignant histiocytosis: a clinico-pathological study of 12 cases. $\mathrm{Br}$ J Haematol 1978, 40: 65-77.

4. Risdall, R.J., McKenna, R.W., Nexbit, M.E. et al. Virus-associated hemophagocytic syndrome. A benign histiocytic proliferation distinct from malignant histiocytosis. Cancer 1979, 44: 993-1002.

5. Risdall, R.J., Brunning, R.D., Hernandez, J.I. \& Gordon, D.H. Bacteria-associated hemophagocytic syndrome. Cancer 1984, 54: 2968-2972.

6. Economopoulos, T.C., Stathakis, N., Stathopoulos, E. \& Alexopoulos, C. 'Lennert's lymphoma' terminating as malignant histiocytosis. Scand J Haematol 1979, 23: 427-432.

7. Jaffe, E.S., Costa, J., Fauci, A.S., Cossman, J., Tsokos, M. Malignant lymphoma and erythrophagocytosis simulating malignant histiocytosis. Am J Med 1983, 75: $741-649$.

8. Liang, D.C., Chu, M.L. \& Shih, C.C. Reactive histiocytosis in acute lymphoblastic leukemia and nonHodgkin's lymphoma. Cancer 1986, 58: 1289-1294.

9. Castoldi, G., Grusovin, G.D., Scapoli, G., Gualandi, M., Spanedda, R. \& Anzanel, D. Acute myelomonocytic leukemia terminating in histiocytic medullary reticulosis. Cytochemical, cytogenetic and electron microscopic studies. Cancer 1977, 40: 1735-1747.

10. Manoharan, A., Catovsky, D., Lampert, I.A., Mashadhani, A., Gordon-Smith, E.C. \& Galton, D.A.G. Histiocytic medullary reticulosis complicating chronic lymphocytic leukaemia: malignant or reactive. Scand $J$ Haematol 1981, 26: 5-13.

11. Korman, L.Y., Robert-Smith, J., Landaw, S.A. \& Davey, F.R. Hodgkin's disease: intramedullary phagocytosis with pancytopenia. Ann Intern Med 1979, 91: $60-61$.

12. Schumacher, H.R. \& Stass, S.A. Histiocytic medullary reticulosis. Lancet 1979, i: 58.

13. Manoharan, A. \& Catovsky, D. Histiocytic medullary reticulosis revisited. In: Schmalze, Huhn \& Schaeffer (eds) Haematology and Blood Transfusion, vol. 27. Disorders of the Monocyte Macrophage System. Springer Verlag, Berlin, 1981, pp. 205-210.

14. Clark, B.S. \& Dawson, P.J. Histiocytic medullary reticulosis presenting with a leukemic blood picture. Am J Med 1969, 47: 314-317.
15. Skarin, A.T., Karb, K. \& Reynolds, E.S. Acute leukemiaç terminating in histiocytic medullary reticulosis. Arch Pathol 1972, 93: 256-260.

16. Warnke, R.A., Kim, H. \& Dorfinan, R.F. Malignant histiocytosis (histiocytic medullary reticulosis): clinico- $\frac{\varrho}{2}$ pathologic study of 29 cases. Cancer 1975, 35: 215-230.

17. Sheriner, D.P. Acute lymphoblastic leukemia terminating as histiocytic medullary reticulosis. $J A M A$ 1975, 231: $838-840$.

18. Chen, T.K., Nesbit, M.E., McKenna, R. \& Kersey, J.H. Histiocytic medullary reticulosis in acute lymphocytic $\frac{\text { }}{7}$

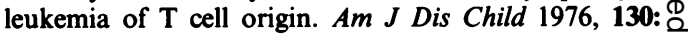
1262-1264.

19. Karcher, D.S., Head, D.R. \& Mullins, J.D. Malignant ${ }^{\infty}$ histiocytosis occurring in patients with acute lym-? phocytic leukemia. Cancer 1978, 41: 1967-1973.

20. Starkie, C.M., Kenny, M.W., Mann, J.R., Cameron, A.M. \& Hill, F.G.H. Histiocytic medullary reticulosisfollowing acute lymphoblastic leukemia. Cancer 1981, 47: $537-544$.

21. Chesney, T.M. Histiocytic medullary reticulosis (malignant histiocytosis) as a sequel of acute lymphoblastic leukemia in childhood. Blood 1979, 50 (suppl): 186.

22. Skoog, D.P. \& Feagler, J.R. T-cell acute lymphocytic iv leukemia terminating as malignant histiocytosis. $A m J \overrightarrow{0}$ Med 1978, 64: 678-682.

23. Griffin, J.D., Ellman, L., Long, J.C. \& Dvorak, A.M. Development of a histiocytic medullary reticulosis-like $D$ syndrome during the course of acute lymphocytic음 leukemia. Am J Med 1978, 64: 851-858.

24. Trubowitz, S., Sobel, H. \& Davis, S. Null cell (non- $\overrightarrow{\Phi,} \vec{\oplus}$ non-B) acute lymphoblastic leukemia terminating \& malignant histiocytosis. Am J Clin Pathol 1980, 725-730.

25. Martelli, M.F., Tabilio, A., Aversa, F., Falini, B. : Rocchi, F. Is histiocytic medullary reticulosis an infec-̄o tious disease? Lancet 1982, ii: 446-447.

26. Yin, J.A.L., Kumaran, T.O., Marsh, G.W., Rossiter, M. \& Catovsky, D. Complete recovery of histiocytic medul- $\underset{F}{F}$ lary reticulosis-like syndrome in a child with acute $\frac{\text { O }}{3}$ lymphoblastic leukemia. Cancer 1982, 51: 200-202.

27. Rosner, F. \& Grunwald, H.W. Association of T-cell acute lymphoblastic leukemia and histiocytic medullary reticulosis. Am J Med 1984, 77: 910-914.

28. Esumi, N., Ikushima, S., Hibi, S., Todo, S. \& Imashuru, S. High serum ferritin level as a marker of malignant histiocytosis and virus-associated hemophagocytic synd rome. Cancer 1988, 61: 2071-2076.

29. Groopman, J.E. \& Gold, D.W. The histiocytic disorder: A pathophysiological analysis. Ann Intern Med 1981, 94:0 95-107. 